\title{
The Dynamics and Estimation of Short-Run Money Demand
}

\author{
R. W. HAFER and SCOTT E. HEIN
}

\begin{abstract}
Ho
STABLE money demand function is crucial to the formation and implementation of effective monetary policy. Consequently, recent findings of temporal instability in this relationship have concerned both policymakers and economists. Previous studies have examined the stability issue by focusing on the "proper" specification of the money demand equation. For the most part, these studies were directed toward discovering which scale variable and interest rates are appropriate. Unfortunately, such attempts to explain the apparent breakdown in the money demand relationship in the early 1970s have not been successful.

Within this literature there is surprisingly little attention devoted to the process by which money bal* ances are assumed to adjust to the desired level. This paper investigates the importance of the moneydemand adjustment process as well as the technique used to estimate this relationship. Both the specification of the adjustment process and the estimation technique employed are shown to be significant factors in determining whether the short-run money demand function has been temporally stable during recent years.
\end{abstract}

\section{BACKGROUND}

In the transactions view of the demand for real money balances, money is held primarily for two reasons: the lack of synchronization between receipts and expenditures and the existence of positive transactions costs. ${ }^{1}$ Formulations of the transactions money

\footnotetext{
In contrast to other analyses which place greater emphasis on money's role as a store-of-value, the transactions approach foeuses on the medium of exchange function played by money in the economy. For an introduction to the transactions approach, see Thomas M. Havrilesky and John T. Boorman, Monetary Macro-Economics (Culington Heights; AHM Publishing Corp. 1978), pp, 96-113. The standard references on this topic are: John Maynard Keynes, The General Theory of Employment, Interest, and Money (London: Harcourt, Brace and Word, 1936); Willian J. Baumol "The Transactions Demand for Cash: An Inventory Theoretic Approach," Quarterly Joumal of Economics (November 1952), pp. 545-
}

demand function relate the demand for real money balances $\left(\mathrm{m}^{\mathrm{t}}\right)$ to "the" interest rate $(\mathrm{r})$ (measured in nominal terms and therefore incorporating inflationary expectations) on assets that are thought to be relatively close substitutes for money and to some measure of economic activity, such as real GNP $(y)$, to capture the volume of transactions undertaken in the economy. Real money balances are conventionally measured by M1 divided by the price level (GNP deflator).

This relationship may be written as:

$$
m^{i}=f(r, y) \text {. }
$$

This relationship is typically estimated in the loglinear form,

$$
\ln m_{t}^{d}=a_{3}+a_{1} \ln r_{t}+a_{2} \ln y_{1}+\varepsilon_{i},
$$

where $\varepsilon$ is a random error term. Furthermore, the transactions demand for money framework suggests that the following restrictions should hold for the estimated regression coefficients:

$$
\left.0 \geq a_{1} \geq-0.5, \text { and }\right] \geq a_{2} \geq 0.5 .^{-2}
$$

Equation 2 often has been estimated directly using annual data. ${ }^{3}$ Because equation 2 represents a long-

56; and James Tobin, "The Interest Elasticity of the Transactions Demand for Cash," The Review of Economics and Statistics (August 1956), pp. 241-47. For an example of money viewed as a storemof-value, see Milton Friedman, "The Quantity Theory of Money; A Restatement," in Milton Friedman, ed., Studies in the Quantity Theory of Money (Chicago: University of Chicago Press, 1956).

2The Balmol-Tobin framework suggests that $a_{\mathrm{E}}=-0.5$ and $a_{2}=-0.5$. For a generalization, see Robert $]$. Barro, "Integral Constraints and Aggregation in Inventory Models of Money Demand," Journal of Finance (March 1976), pp. 77-88.

3 See, for example, Allan $H$. Meltzer, "The Demand for Money: The Evidence from the Time Series," Joumal of Political Economy (Jume 1963), pp. 219-46; T. J. Courchene and H. T. Shapiro, "The Demand for Money: A Note from the Time Series," Jottmal of Political Economy (November 1964), pp. 1205-19; and David E. W. Laidler, "Some Evidence on the Demand for Money," Joumal of Political Economy (April 1966), pp. 111-31. 
run equilibrium in which full adjustment between actual and desired real money balances is completed within one year, no adjustment process is specified.

When equation 2 is estimated with quarterly data, however, a more flexible specification is needed to characterize the short-term money market disequilibria that may exist. To do this, "desired" money balances are posited to depend upon the same variables found in equation 2. Thus,

$$
\ln m_{t}^{i}=a_{s}+a_{1} \ln x_{t}+a_{2} \ln y_{t}+\varepsilon_{t}
$$

where mi represents desired (or long-run) real money balances for period t. ${ }^{*}$ However, since actual real money balances $\left(m_{t}\right)$ and desired holdings $\left(m_{i}^{*}\right)$ may not be equal in the contemporaneous period - because transaction costs prevent immediate adjustment of actual balances to their desired levels - a specific stock-adjustment process is specified.

The most commonly used adjustment mechanism can be formalized as,

(4) $\ln \mathrm{m}_{\mathrm{t}}-\ln \mathrm{m}_{\mathrm{t}-1}=\lambda\left(\ln \mathrm{m}_{\mathrm{t}}^{*}-\ln \mathrm{m}_{\mathrm{t}-1}\right) ;(0 \leq \lambda \leq 1)$, where $\lambda$ represents the coefficient of adjustment the speed at which actual money holdings adjust to the gap between last period's stock and the currently desired level. Substituting equation 3 into equation 4 yields,

(5) $\ln m_{t}-\ln m_{t-1}=\lambda\left[\left(a_{0}+a_{1} \ln r_{t}+a_{2} \ln y_{t}+\varepsilon_{t}\right)-\right.$ In $\mathrm{mt}_{\mathrm{t}}$ ],

which, upon simplification, gives the following solution for $\ln \mathrm{m}_{\mathrm{t}}$ :

$$
\begin{aligned}
\ln m_{1}= & \lambda a_{a}+\lambda a_{1} \ln r_{t}+\lambda a_{2} n y_{2}+ \\
& (1-\lambda) \ln m_{t-1}+\lambda \varepsilon_{i}
\end{aligned}
$$

Equation 6, then, represents a commonly estimated quarterly money demand function. The adjustment coefficient $(\lambda)$ is derived from the estimated coefficient on the lagged dependent variable $\left(\mathrm{ln}_{\mathrm{t}_{-1}}\right)$. If, for example, the estimated coefficient on $\ln \mathrm{m}_{\mathrm{k}-1}$ is 0.7 , this indicates a 30 percent $(1-0.7)$ per gtrarter adjustment of actual money balances to the desired level. Also, whereas the estimated coefficients on $h x_{t}$ and In yt represent the short-run elasticities of real money balances with respect to these variables, dividing these coefficients by the adjustment coefficient $(\lambda)$ yields estimates of these variables long-run elasticities.

Equation 4 has been labeled the real-adjustment

\footnotetext{
Writing equation $(3)$ in nominal form yields, $\ln M_{t}^{0}=a_{0}+a_{1} \ln x_{t}+a_{2} \ln y_{t}+\ln P_{t}+\varepsilon_{t}$

where $\ln \mathrm{P}_{\mathrm{t}}$ is the natural logarithm of the price level in period $t$, and $\ln M^{\circ}$ is the natural logarithm of the desired level of nominal money balances.
}

mechanism. ${ }^{5}$ One important implication of this specification is that a decine in the real value of last period's nominal money stock due to rising prices will be fully and immediately offset by an increase in the amount of nominal money balances currently held. In other words, it is implicitly assumed that an increase in the price level will induce an immediate increase in nominal money holdings to equate the real value of last period's nominal money holdings to the currently desired level.

The real-adjustment mechanism has been criticized on the grounds that the change in money balances due to a price level change will not occur instantaneously because such adjustments are costly - just as they are when interest rates and income change. Goldfeld and White have suggested an alternative adjustment mechanism, commonly referred to as the nominal-adjustment mechanism. ${ }^{\theta}$

The nominal-adjustment hypothesis can be written as,

(7) $\ln M_{t}-\ln M_{t-1}=\lambda^{\prime}\left(\ln M_{:}^{*}-\ln M_{t-1}\right) ;\left(0 \leq \lambda^{\prime} \leq 1\right)$, where $\mathrm{M}$ is nominal money balances, that is, $\bar{M}_{t}=$ $m_{t}\left(P_{t}\right)$. Transforming equation 3 so that the left-hand side is equal to $\ln M_{t}$ and substituting that equation into equation 7 yields,

(8) $\ln \mathrm{M}_{z}-\ln \mathrm{M}_{\mathrm{t}-\mathrm{I}}=\lambda^{\prime}\left[\left(\mathrm{a}_{0}+\mathrm{a}_{1} \ln \mathrm{r}_{2}+\mathrm{a}_{2} \ln \mathrm{y}_{\mathrm{t}}+\right.\right.$ $\left.\left.\ln P_{t}+\varepsilon_{t}\right)-\ln M_{t-1}\right]$.

Solving equation 8 for $\ln M_{t}$ gives,

(9) $\ln M_{t}=\lambda^{\prime} a_{0}+\lambda^{\prime} a_{1} \ln x_{t}+\lambda^{\prime} a_{2} \ln y_{t}+\lambda^{\prime} \ln P_{t}+$ $\left(1-\lambda^{\prime}\right) \ln \mathrm{M}_{\mathrm{t}-3}+\lambda^{\prime} \varepsilon_{\mathrm{t}}$.

The dependent variable in equation 9 is specified in nominal terms. Equation 9 usually has been estimated, however, with real money balances as the dependent variable. To transform the nominal-adjustment specification so that real money balances are on

"This nomenclature follows that used by Stephen M. Coldfeld, "The Case of the Missing Money," Brookings Papers on Economic Actitity (3:1976), pp. $683-730$.

A specification very similar to equation (6) can be generated if one assumes that the appropriate levels of the dependent variables are formed adaptively. Thus, the dynamics of the adiustment process could be due to expectation fomation, rather than transactions costs. See David E. W. Laidler, The Demand for Money, 2nd. ed., (New York: Dumn-Domelley, 1977 ), pp. $142-43$.

"See Stephen M. Goldfeld, "The Demand for Noney Revisited," Brookings Papers on Economic Activity (3: 1973), pp. 577-638, and "The Case of the Missing Money," Brookings Papers on Economic Activity (3: 1973), pp. 683-730, Willam H. White, "Improving the Demand-for-Money Function In Moderate Inflation," International Monetary Fund Staff Pepers (September 1978), pp. 564-607, The nominal-adjustment mechanism discassed here is used in the MPS (MIT-PennSocial Science Research Council) demand deposits equation. See Jared Enzler, Lewis Johnson, and John Paulus, "Some problems of Money Demand," Brookings Papers on Economic Activity (1: 1976), pp. 261-79. 
the left-hand side, $\ln \mathrm{P}_{\mathrm{t}}$ must be subtracted from both sides of equation 9 :

(10) $\ln M_{t}-\ln P_{t}=\lambda_{a_{0}}^{\prime}+\lambda_{a_{1}}^{\prime} \ln r_{t}+\lambda_{a}^{\prime} \ln y_{t}-$ $\left(1-\lambda^{\prime}\right) \ln P_{t}+\left(1-\lambda^{\prime}\right) \ln M_{t-1}+\lambda^{\prime} \varepsilon_{t}$.

Equation 10 can then be rewritten in the form,

(11) $\quad \ln m_{t}=\lambda^{\prime} a_{0}+\lambda^{\prime} a_{1} \ln r_{t}+\lambda^{\prime} a_{2} \ln y_{s}+$

$$
\left(1-\lambda^{\prime}\right) \ln \left(M_{\mathrm{t}-1} / \mathrm{P}_{\mathrm{t}}\right)+\lambda^{\prime} \varepsilon_{\mathrm{t}}
$$

Thus, the only difference between the estimation of the real-adjustment specification (equation 6) and the nominal-adjustment specification (equation 11) is the form of the lagged dependent variable. In the real-adjustment version, lagged nominal money balances are deflated by lagged prices. In the nominaladjustment version, they are deflated by current prices. $^{\top}$

\section{EMPIRICAL EVIDENCE}

\section{Cochrane-Orcutt Results}

Goldfeld found little empirical difference between the coefficient estimates of the real- and nominaladjustment specifications. Based on a superior fit, both in- and out-of-sample, however, he favored the nominal adjustment version. Friedman, on the other hand, provides contrasting evidence which suggests that the real-adjustment version provides more stable regression coefficients over different sample periods. ${ }^{8}$

Tables 1 and 2 summarize the empirical evidence on the real- and nominal-adjustment specifications of

${ }_{7}^{7}$ Heller and Khan recently have questioned the applicability of the nominal-adjustment speciffcation. See H. Robert Heller and Mohsin S. Khan, "The Demand for Money and the Tem Structure of Interest Rates," Journal of Political Economy (February 1979), pp. 109-29. The issue raised by Heller and Khan is essentially an econometric one. Specifically, estimation of the nominal-adjustment version within a single-equation framework will avoid econometric problems associated with simultaneous equations bias only when the dependent variable is viewed as being determined by the exogenous v'ariables specified on the right-hand side of the equation.

Although Heller and Khan suggest that a simultaneous equations bias is present when the nominal-adjustment version is estimated, this same criticism applies equally to the real-adjustment specification. Two points should be recognized with respect to the Heller-Khan criticism. First, empirical estimates of the nominal-adjustment specification traditionally define the dependent variable to be real noney balances, not nominal money balances as given by equation 7 . In a very important sense this variable can be viewed as demand determined that is, determined by the price level, interest rates, and real income. Second, and perhaps more impertantly, the simultaneous equation bias which results from estimating money demand relationships in a single equation framework is quite small. For a recent example of studies addressing the possibility of simultaneous equation bias, see Goldfeld, "The Demand for Money Revisited" and "The Case of the Missing Money,"

8Benjamin Friedman, "Crowding Out or Crowding In?: Economic Consequences of Financing Govemment Deficits," Brookings Papers on Economic Activity (3: 1978), pp. 593641. This evidence is found in his tables, but never discussed. the money demand relationship. ${ }^{9}$ The estimated coefficients for the sample period II/1955-IV/1962 are reported first, followed by estimates obtained by lengthening the sample period in increments of four quarters. Relevant summary statistics as weli as the static root-mean-squared error (RMSE) for the four quarters immediately following the end of the sample period are also presented. Except for the sample period II/1955-IV/1978, all regressions are estimated using the Cochrane-Orcutt (CORC) serial correlation correction technique - the technique most commonly implemented to estimate money demand when quarterly data are employed. ${ }^{10}$

The regression results for the real- and nominaladjustment specifications (tables 1 and 2 , respectively) from various sample periods up to and including the II/1955-IV/1973 period are consistent with the results of previous investigations. ${ }^{11}$ In addition, the coefficients on the real income and interest rate variables are similar across adjustment specifications. The nominal-adjustment specification continually produces, as Goldfeld noted, a slightly slower speed of adjustment.

"Following Goldfeld, "The Demand for Money Revisited," these specifications incorporate two interest rates. The com* mereial paper rate (CPR) is included as a proxy for market rates of return. The commercial bank passbook rate (RTD) is included also. Banking regulations prevent this latter rate from totally moving with the market rate of return. Small investors, who do not have sufficient funds to invest in market assets, may be sensitive to the yield on passbook rates.

10The last row of table 1 presents the regression results when an alternative serial correlation adjustment procedme is used. This alternative - known as Hildreth-Lu (HILU) - was employed because of the drastic change in the rho estimate found when adding the observations for 1978 using the CORC. procedure. As seen in the table, CORC estimates of tho increase in value as the sample period is extended. When 1978 observations are added, however, the CORC estimate of tho dropped dranaticaly to 0,466 . The HILU results, however, suggest that the "correct" tho value for the IV/1955-IV/1978 sample estimation is 0.980 .

This finding indicates that the Cochrane-Orcutt technique. when applied to the II/1955-IV/1978 sample, had iterated to a local rather than a global minimum of the sum-ofsquared residuals. This type of problem, althongh recognized in the econometries literature, has received little attention in regard to estimating money demand functions. Interestingly enough, while the Cochramemorcutt estimates revealed a significant change in the coefficients once the observations for 1978 were added, this deterioration is not evident when the Hildreth-Lu estimation technique is used: The estimated com efficients on the passbook rate and income variables continue to have the anticipated sign and are statistically different from zero. In addition, the coefficient on the lagged dependent variable is comparable to that found for earlier sample periods. None of these findings were obtained when the Cochrane-Orcutt estimation procedure was employed for the II/1955-IV/1978 sample period.

For a discussion of the problems associated with the Cochrane-Orcutt technique, see J. Johnston, Econometric Methods, 2nd ed., (New York: McGraw-Hill, 1972), pp. $262-63$.

1See Goldfeld, "The Case of the Missing, Money;" Enzler, Johnson, and Paulus, "Some Problems;" and Friedman, "Crowding Out or Crowding In?" 


\section{Table 1}

\section{Real-Adjustment Version (log-level equation)}

\begin{tabular}{|c|c|c|c|c|c|c|c|c|c|c|c|}
\hline \multirow{2}{*}{$\begin{array}{l}\text { Estimation } \\
\text { technigue }\end{array}$} & \multirow{2}{*}{ Sample } & \multicolumn{5}{|c|}{ Coefficients (absolute value of tratatistics in } & \multirow[b]{2}{*}{9} & \multirow[b]{2}{*}{ Durbin } & \multirow{2}{*}{$\begin{array}{r}\text { SEE } \\
\times 10 \\
\end{array}$} & \multirow[b]{2}{*}{ Mho } & \multirow{2}{*}{$\begin{array}{c}\text { Staloc } \\
40 \\
710 \\
\times 10\end{array}$} \\
\hline & & $\mathrm{c}$ & nots & In $\mathrm{CPR}_{4}$ & In $\mathrm{BT}$ P & $P$ & & & & & \\
\hline core & $11 / 1955$ w/1962 & $(0,644)$ & 0.140 & $(4.11)$ & $(2.039)$ & 0.698 & 0.9494 & 0.029 & 0.3800 & 0.256 & 0,60 \\
\hline cone & $11,1955,1 / 1963$ & $(3.13)$ & $(0,369)$ & $\begin{array}{l}0.018 \\
(4.07)\end{array}$ & $(2.01)$ & 0,710 & 0.9494 & 0.034 & 0.3762 & 0.351 & 0.55 \\
\hline coro & $111955-1 / 1964$ & $(3.93)$ & $(3.92)$ & $\begin{array}{l}0.018 \\
(4.08)\end{array}$ & $\begin{array}{l}-0,040 \\
(2,81)\end{array}$ & $(0,742$ & 0.9651 & 0,18 & 0,3741 & 0.371 & 052 \\
\hline conc & $11,195510 / 1965$ & $(4.37)$ & $(0,286$ & $\begin{array}{l}0.019 \\
(4.29)\end{array}$ & $(3.08)$ & $(8.25)$ & 09774 & 0365 & 0.3786 & 0.303 & 1.00 \\
\hline oone & $1 / 1955-1 / 1960$ & $(3,405)$ & $(0,44)$ & $(4,021$ & $\begin{array}{l}0.032 \\
(2.32)\end{array}$ & $\begin{array}{l}0724 \\
(759)\end{array}$ & 0.9818 & 0.614 & 0.4058 & 0.440 & 0.42 \\
\hline oone & $11 / 1955.1 / 1967$ & $\frac{-0.842}{(4.43)}$ & 0.770 & $(4.48)$ & 0.037 & 0708 & 0.9866 & 0.569 & 0.0994 & 0.406 & 0.44 \\
\hline cond & $1171955-\mathrm{W} / 1968$ & $(4.909)$ & $(4.72)$ & $(4.49)$ & $\begin{array}{l}0.089 \\
(3.27)\end{array}$ & $\begin{array}{r}0.703 \\
(8.27)\end{array}$ & 099905 & 0748 & 0,3956 & 0942 & 0.41 \\
\hline conc & $11 / 1955 / 1 / / 1969$ & $\begin{array}{l}0.905 \\
(5.04)\end{array}$ & $(0.81)$ & $(5.023)$ & $(0.040)$ & $\begin{array}{l}0.698 \\
(0.53)\end{array}$ & 0.9925 & 0.811 & 03043 & 0.422 & 0.31 \\
\hline cons & $11 / 1955-$ W/ 1970 & $(5,23)$ & $\begin{array}{l}0,04 \\
(5,09)\end{array}$ & $(6,022$ & $(0,009)$ & $\begin{array}{l}0.688 \\
(0.71)\end{array}$ & 0,9933 & 0.932 & 0.3875 & 0422 & 0.68 \\
\hline core & $117955+11 / 1974$ & $(09916$ & $\begin{array}{l}0,79 \\
(484)\end{array}$ & $\begin{array}{r}0.017 \\
(422)\end{array}$ & $(3,38)$ & $\begin{array}{l}0,661 \\
(8,2)\end{array}$ & 0,9933 & 1,381 & 0.4074 & 0.425 & 0,00 \\
\hline conc & $1 / / 1955-1 v / 1972$ & $(5,861)$ & 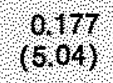 & $(457)$ & $\begin{array}{l}0.040 \\
(3.51)\end{array}$ & $\begin{array}{r}0,655 \\
(8,6)\end{array}$ & 0.9945 & 1321 & 04000 & 0.440 & 0.51 \\
\hline GorC & $11 / 1055-14 / 1973$ & $\begin{array}{l}0.867 \\
(5.24)\end{array}$ & $(5.180$ & $\begin{array}{l}0,016 \\
(4.70)\end{array}$ & $(3.040$ & $\begin{array}{l}0.649 \\
(8.28)\end{array}$ & 0.9952 & 1,460 & 0.4049 & 0,440 & 1.61 \\
\hline cono & $11 / 19551 \mathrm{~V} 1974$ & $\begin{array}{l}0,703 \\
(3,00)\end{array}$ & 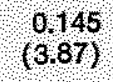 & 8022 & 0,032 & $\begin{array}{l}0.732 \\
(8.54)\end{array}$ & 0,9940 & 1125 & 0,4596 & 0.596 & 190 \\
\hline cofo & $11 / 1955-17 / 1975$ & $(3,69)$ & $\begin{array}{r}0,55 \\
(430)\end{array}$ & $\begin{array}{l}0.014 \\
(301)\end{array}$ & 20,048 & 0,676 & 0,9923 & 0,305 & 0.5051 & 0.871 & 0.65 \\
\hline cone & $11 / 1955-1 V / 1976$ & $\begin{array}{l}0.702 \\
(3.52)\end{array}$ & $(4,45)$ & $(2.95)$ & $\begin{array}{l}0,050 \\
(274)\end{array}$ & $\begin{array}{l}0.652 \\
(7,70)\end{array}$ & 0,0922 & 0,278 & 0,4984 & 0.910 & 0,62 \\
\hline cono & $11 / 1955-1 V / 1977$ & $\begin{array}{r}0,688 \\
(3,41)\end{array}$ & $\begin{array}{l}0,156 \\
(4,50)\end{array}$ & $\begin{array}{l}0.013 \\
(2,88)\end{array}$ & $\begin{array}{l}0050 \\
(272)\end{array}$ & $\begin{array}{l}0.632 \\
(751)\end{array}$ & 0.9912 & $-0,097$ & 0.4970 & 0925 & 1,17 \\
\hline$(1,0,0,01)$ & $11055 \mathrm{U} / 1078$ & $\begin{array}{r}0.919 \\
(2,43)\end{array}$ & $\begin{array}{l}0.190 \\
(3.47)\end{array}$ & $\begin{array}{r}-0.014 \\
(3.15)\end{array}$ & $\begin{array}{r}0.045 \\
(2.33)\end{array}$ & $\begin{array}{r}0.583 \\
(6.78)\end{array}$ & 0,9912 & 0386 & 05096 & 0980 & 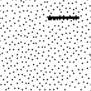 \\
\hline
\end{tabular}

This specification also yields smaller standard errors of the estimating equation (SEE) and superior postsample predictions in terms of the static RMSEs.

The regression results for sample periods with end points beyond IV/1973, however, provide a different picture. As the end point is advanced, all estimated coefficients for the real-adjustment specification continue to have their anticipated sign, are different from zero at traditional levels of significance, and show relatively small changes in magnitude. There is, however, a significant change in the estimated value of the serial correlation coefficient ( 0.44 for the period ending IV/1973 to 0.98 for the period ending IV/1978). While the change in the rho value has no economic significance, it suggests a misspecification problem. Moreover, the results indicate a marked deterioration in both the in- and out-of-sample fit. Altogether, the SEE increases 26 percent and, for the years 1974 and 1975 , the RMSE is more than triple that observed for 1973.

The increase in the RMSE, however, does not tell the whole story. A major problem with the post- 
Table 2

Nominal-Adjustment Version (Cochrane-Orcutt estimation of log-level equation)

\begin{tabular}{|c|c|c|c|c|c|c|c|c|c|c|}
\hline \multirow{2}{*}{$\begin{array}{l}\text { Sample } \\
\text { period }\end{array}$} & \multicolumn{5}{|c|}{ Coefficlents (absolute value of t-statistics in parentheses) } & \multirow[b]{2}{*}{$R^{2}$} & \multirow[b]{2}{*}{$D W$} & \multirow{2}{*}{$\begin{array}{c}S E E \\
\times 10^{-}\end{array}$} & \multirow[b]{2}{*}{ Aho } & \multirow{2}{*}{$\begin{array}{l}\text { Statio } \\
4 Q \\
\text { AMSE } \\
\times 10^{-}\end{array}$} \\
\hline & $\mathrm{a}$ & $n y_{0}$ & $\mathrm{CAPA}$ & $1 \mathrm{RTD}_{\mathrm{C}}$ & $\ln \left(\mathrm{M}_{-} / \mathrm{P}\right)$ & & & & & \\
\hline $11 / 1955-14 / 1962$ & $\begin{array}{r}0.625 \\
(2.20)\end{array}$ & $\begin{array}{r}0,128 \\
(254)\end{array}$ & $\begin{array}{r}-0,017 \\
(3,76)\end{array}$ & $\begin{array}{r}0,032 \\
(2,35)\end{array}$ & $\begin{array}{l}0,780 \\
(7,11)\end{array}$ & 0,9584 & 1.81 & 0.3457 & 0,4922 & 0.50 \\
\hline $1 / 1955 / V / 1963$ & $\begin{array}{l}0.777 \\
(3.03)\end{array}$ & $\begin{array}{r}0,148 \\
(3,7)\end{array}$ & $\begin{array}{r}0.018 \\
(3.98)\end{array}$ & $\begin{array}{r}0.033 \\
(252)\end{array}$ & $\begin{array}{l}0.811 \\
(773)\end{array}$ & 09608 & 183 & 0,3314 & 0,5456 & 0.40 \\
\hline $11 / 1955 \mathrm{wV} / 1964$ & $\begin{array}{l}0.841 \\
(3.62)\end{array}$ & $\begin{array}{r}0,56 \\
(353)\end{array}$ & $\begin{array}{l}0,018 \\
(4,77)\end{array}$ & $\begin{array}{r}-0,035 \\
(2,69)\end{array}$ & $\begin{array}{l}0.825 \\
(8,14)\end{array}$ & 0,9723 & 1,85 & 0.3337 & 05231 & 0,38 \\
\hline $1 / 1955-1 / 1965$ & $\begin{array}{l}0,836 \\
(4,10)\end{array}$ & $\begin{array}{r}0,57 \\
(3,84)\end{array}$ & $\begin{array}{r}0.018 \\
(4.30)\end{array}$ & $\begin{array}{r}-0,035 \\
(2.90)\end{array}$ & $\begin{array}{l}0.816 \\
(9.01)\end{array}$ & 0,9827 & 175 & 0.3316 & 0,4917 & 0.91 \\
\hline $1 / 1955-1 / / 1966$ & $\begin{array}{l}0.699 \\
(3.43)\end{array}$ & $\begin{array}{r}0,136 \\
(329)\end{array}$ & $\begin{array}{r}0,020 \\
(4,14)\end{array}$ & $\begin{array}{r}0,030 \\
(2,35)\end{array}$ & $\begin{array}{l}0.808 \\
(0.22)\end{array}$ & 0,9852 & 165 & 03670 & 0.5559 & 0.56 \\
\hline $1 / / 955-1 / / 1967$ & $\begin{array}{l}0,810 \\
(436)\end{array}$ & $\begin{array}{r}0156 \\
(402)\end{array}$ & $\begin{array}{r}0,020 \\
(4,35)\end{array}$ & $\begin{array}{r}0,035 \\
(293)\end{array}$ & $\begin{array}{l}0.787 \\
(8.20)\end{array}$ & 0,9882 & 170 & 0,3746 & 05067 & 0.50 \\
\hline $1 / / 1955-\mathrm{N} / 1968$ & 0.866 & $\begin{array}{r}0,164 \\
(4.38)\end{array}$ & $\begin{array}{l}-0,021 \\
(4,39)\end{array}$ & $\begin{array}{r}0,038 \\
(3,24)\end{array}$ & $\begin{array}{r}0.794 \\
(8.54)\end{array}$ & 0,9917 & 170 & 0.3707 & 0.5307 & 0.33 \\
\hline $1 / 1955 / V / 1969$ & $\begin{array}{l}0.861 \\
(5.04)\end{array}$ & $\begin{array}{r}0,64 \\
(4.56)\end{array}$ & $\begin{array}{r}0,022 \\
(5,00)\end{array}$ & $\begin{array}{r}0,038 \\
(3.34)\end{array}$ & $\begin{array}{r}0,792 \\
(911)\end{array}$ & 09937 & 169 & 03625 & 0,5270 & 0,33 \\
\hline $11 / 1955 / \mathrm{N} / 1970$ & $-0,855$ & $\begin{array}{r}0163 \\
(4.65)\end{array}$ & $\begin{array}{l}-0.021 \\
(5.06)\end{array}$ & $\begin{array}{r}0.037 \\
(3.36)\end{array}$ & $\begin{array}{l}0.793 \\
(9.42)\end{array}$ & 09944 & 167 & 0,3534 & 0.5285 & 0.72 \\
\hline $1 / 1955-1 / 197$ & $\begin{array}{l}0.839 \\
(5.05)\end{array}$ & $\begin{array}{l}0166 \\
(4,72)\end{array}$ & $\begin{array}{l}0.016 \\
(4.05)\end{array}$ & $\begin{array}{r}0.038 \\
(3,42)\end{array}$ & $\begin{array}{l}0.737 \\
(8.67)\end{array}$ & 0.9942 & 1.56 & 0,3769 & 0,5340 & 018 \\
\hline In/ $1955 \mathrm{~N} / 1972$ & $\begin{array}{r}0,833 \\
(5,42)\end{array}$ & $\begin{array}{r}0.164 \\
(4.98)\end{array}$ & $\begin{array}{l}0.016 \\
(4.57)\end{array}$ & $\begin{array}{r}0.038 \\
(3.57)\end{array}$ & $\begin{array}{l}0.743 \\
(9.17)\end{array}$ & 0.9954 & 1.69 & 0,3686 & 0.5321 & 0.22 \\
\hline $1 / 1955-1 / / 1973$ & $\begin{array}{r}0.809 \\
(5,45)\end{array}$ & $\begin{array}{r}0.160 \\
(501)\end{array}$ & $\begin{array}{l}0,016 \\
(471)\end{array}$ & $\begin{array}{r}-0.037 \\
(3.56)\end{array}$ & $\begin{array}{l}0.748 \\
(0.60)\end{array}$ & 0,9961 & 172 & 0.3644 & 0,5145 & 0,66 \\
\hline $1 / 1955 \mathrm{~N} / 1974$ & $\begin{array}{l}0.656 \\
(5.15)\end{array}$ & $\begin{array}{l}0125 \\
(464)\end{array}$ & $\begin{array}{r}0017 \\
(5.69)\end{array}$ & $\begin{array}{r}0.027 \\
(297)\end{array}$ & $\begin{array}{l}0.840 \\
(13,22)\end{array}$ & 0.9961 & 178 & 0.3679 & 0.4967 & 1.56 \\
\hline II/1955 NV/1975 & $\begin{array}{r}-0,327 \\
(3,40)\end{array}$ & $\begin{array}{r}0.054 \\
(2.72)\end{array}$ & $\begin{array}{l}0.015 \\
(4.68)\end{array}$ & $\begin{array}{r}0.008 \\
(0.99)\end{array}$ & $\begin{array}{r}1003 \\
(2171)\end{array}$ & 09948 & 179 & 0,4161 & 0.4242 & 0.69 \\
\hline II/1955-IV/1976 & $\begin{array}{r}0,233 \\
(3,32)\end{array}$ & $\begin{array}{r}0,034 \\
(240)\end{array}$ & $\begin{array}{r}0.014 \\
(4.58)\end{array}$ & $\begin{array}{r}-0.002 \\
(0.26)\end{array}$ & $\begin{array}{r}1.045 \\
(29.39)\end{array}$ & 0.9945 & 1.88 & 0.4183 & 0.3990 & 0.16 \\
\hline $1 / 1955-\mathrm{V} / 1977$ & $\begin{array}{r}-0.227 \\
(3.97)\end{array}$ & $\begin{array}{l}0,033 \\
(2,91)\end{array}$ & $\begin{array}{r}-0.014 \\
(4.67)\end{array}$ & $\begin{array}{r}-0.001 \\
(0.23)\end{array}$ & $\begin{array}{r}1,047 \\
(34,02)\end{array}$ & 0,9945 & 189 & 0.4102 & 0.3929 & 0.38 \\
\hline $1 / / 1955-1 \mathrm{~V} / 1978$ & $\begin{array}{c}0.233 \\
(4.55)\end{array}$ & $\begin{array}{r}0,034 \\
(3,49)\end{array}$ & $\begin{array}{r}-0.014 \\
(4.98)\end{array}$ & $\begin{array}{r}-0.002 \\
(0.29)\end{array}$ & $\begin{array}{r}1.046 \\
(3893)\end{array}$ & 0.9943 & 1,88 & 0,4093 & 0.3886 & 7 \\
\hline
\end{tabular}

sample performance of the real-adjustment equation is that the specification consistently overpredicts money demand. Table 3 provides the mean forecast error for nominal money balances based on both the real- and the nominal-adjustment specifications. The real-adjustment specification, on average, overpredicts money demand for each year following 1973. While the apparent stability of the estimated coefficients provides some ad hoc evidence for the belief that the underlying economic relationship for the real-adjustment specification is stable, the changes in both the rho estimate and the in- and out-of-sample fit question such a conclusion.
In contrast, the results for the nominal-adjustment version over the post-1973 era (table 2) indicate a marked deterioration in the estimated regression co* efficients. This is somewhat surprising since the only difference between these two specifications is whether lagged money is deflated by lagged or contemporaneous prices. Interestingly enough, the most troublesome result over this period is the increase in the size of the coefficient on the lagged dependent variable. The coefficient exceeds unity in the longer sample periods, a finding that alone obviates any meaningful interpretation of the estimates within the stock-adjustment framework. Based on the dramatic change in the 
Table 5

Real-Adjustment Version: Log Differences (ordinary least squares)

\begin{tabular}{|c|c|c|c|c|c|c|c|c|c|}
\hline & \multicolumn{5}{|c|}{ coeficients (absolute value of t-statstics in parentheses) } & \multirow[b]{2}{*}{ n } & \multirow[b]{2}{*}{ burbint } & \multirow[b]{2}{*}{$\begin{array}{l}\text { SEE } \\
\times 10\end{array}$} & \multirow{2}{*}{ 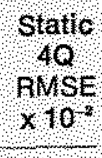 } \\
\hline Period & Constant & $\begin{array}{l}n y_{1}+\text { ? } \\
\text { n }\end{array}$ & $\begin{array}{l}\mathrm{n} \mathrm{CPR}_{4}, \\
\mathrm{CPP}\end{array}$ & $\mathrm{nRO}_{0}$ & $\mathrm{ln}_{\mathrm{n}} \mathrm{M}_{\mathrm{l}} / \mathrm{P}_{\mathrm{P}} \mathrm{s}$ & & & & \\
\hline $11 / 1955 \mathrm{~N} / 1962$ & $\begin{array}{l}0,0001 \\
(0.084)\end{array}$ & $\begin{array}{r}0,147 \\
(159)\end{array}$ & $\frac{0.014}{(2.31)}$ & $\begin{array}{r}0,042 \\
(2.15)\end{array}$ & $\begin{array}{r}0,536 \\
(3,21)\end{array}$ & 0.459 & 294 & 0.4598 & 032 \\
\hline $11 / 1955 / 1 / 1963$ & $\begin{array}{l}0,0003 \\
(0,22)\end{array}$ & $\begin{array}{l}0,156 \\
(1,76)\end{array}$ & $\begin{array}{r}0.014 \\
(2.55)\end{array}$ & $\begin{array}{r}0.047 \\
(2.54)\end{array}$ & $\begin{array}{l}0.571 \\
(3.85)\end{array}$ & 0.524 & 205 & 0.4421 & 0.35 \\
\hline $1 / 1955 / 1 / 1964$ & $(0,73)$ & $\begin{array}{r}0,138 \\
(166)\end{array}$ & $\frac{-0.015}{(275)}$ & $\begin{array}{l}0.050 \\
(286)\end{array}$ & $(0.639$ & 0.581 & 1,80 & 04295 & 0,60 \\
\hline $1 / 955-1 / 1965$ & $\begin{array}{l}0,0001 \\
(0,64)\end{array}$ & $\begin{array}{r}0,46 \\
(176)\end{array}$ & $\begin{array}{l}0.015 \\
(2.66)\end{array}$ & $\begin{array}{r}0.051 \\
(2.81)\end{array}$ & $(4.592$ & 0.539 & 4.44 & 0,4493 & 0.53 \\
\hline $11 / 1955-\mathrm{V} / 1966$ & $\begin{array}{l}0.0009 \\
(0.09)\end{array}$ & $\begin{array}{r}0,51 \\
(1,81)\end{array}$ & $\begin{array}{l}0,016 \\
(285)\end{array}$ & $(2,44)$ & $\left(\begin{array}{l}0.590 \\
(4.65)\end{array}\right.$ & 0.523 & 1.06 & 0.4547 & 0.55 \\
\hline $1179554 \mathrm{~W} / 1007$ & $\begin{array}{l}0,0004 \\
(0,40)\end{array}$ & $(1,93)$ & $(0,018)$ & $(2,6048$ & $(4.576$ & 0.530 & 0,72 & 0.4623 & 038 \\
\hline $11 / 1955-1 / 1968$ & $\begin{array}{l}0,0004 \\
(0,46)\end{array}$ & $\begin{array}{l}0,175 \\
(2,19)\end{array}$ & $(0,018$ & $\begin{array}{l}0,050 \\
(2,79)\end{array}$ & $\begin{array}{r}0.574 \\
(5.24)\end{array}$ & 0.540 & -0.60 & 0,4557 & 0.48 \\
\hline $11 / 1955 \mathrm{~V} / 1069$ & $\begin{array}{l}0,000) \\
(0,14)\end{array}$ & $\begin{array}{l}0,194 \\
(2,9)\end{array}$ & $\begin{array}{l}0.020 \\
(3.72)\end{array}$ & $(2,69)$ & $(5.57)$ & 0.546 & 0,61 & 0.4567 & 0.31 \\
\hline $11 / 19551 \% / 1970$ & 0,00002 & $\begin{array}{l}0.206 \\
(2,80)\end{array}$ & $\begin{array}{l}0,019 \\
(3,75)\end{array}$ & $\begin{array}{r}0.045 \\
(2,69)\end{array}$ & $(5,547)$ & 0.541 & 0,38 & 0.4478 & 0.75 \\
\hline $11 / 1955$ W/1971 & $\begin{array}{l}0,0000 \\
(0,37)\end{array}$ & $\begin{array}{l}0,157 \\
(2,20)\end{array}$ & $(2,013$ & $(20049)$ & $\begin{array}{l}0,529 \\
(5,16)\end{array}$ & 0,492 & 0.60 & 0,4665 & 0.40 \\
\hline U & $\begin{array}{l}0,0004 \\
(0,53)\end{array}$ & $\begin{array}{l}0,66 \\
(243)\end{array}$ & 0,013 & $(0,052$ & $(0,61)$ & 0.527 & 0,28 & 0.4614 & 0.53 \\
\hline $11955-141973$ & $\begin{array}{l}0,0002 \\
(0,23)\end{array}$ & $\begin{array}{l}0171 \\
(256)\end{array}$ & $\begin{array}{l}0013 \\
(290)\end{array}$ & 0,051 & $(5,66)$ & 0.528 & 0.30 & 0,4650 & 0.84 \\
\hline $1 / 1955 / N / 974$ & $\begin{array}{l}0,0005 \\
0,64)\end{array}$ & $\begin{array}{r}0,208 \\
(3,04)\end{array}$ & $\begin{array}{l}0,015 \\
(3,46)\end{array}$ & $\begin{array}{l}0,045 \\
(256)\end{array}$ & $\begin{array}{l}0,609 \\
(6,43)\end{array}$ & 0.587 & 105 & 0.4872 & 078 \\
\hline $11 / 1955 \mathrm{~W} / 1975$ & $\begin{array}{l}0,001 \\
1301\end{array}$ & $\begin{array}{l}0.252 \\
(3.93)\end{array}$ & $\begin{array}{l}0,014 \\
(3,14)\end{array}$ & $(2,44)$ & $\begin{array}{l}0.567 \\
(6.40)\end{array}$ & 0.583 & -0.53 & 0.5041 & 0,28 \\
\hline $11 / 955 \mathrm{~W} / 976$ & $\begin{array}{l}0,001 \\
1,33)\end{array}$ & $\begin{array}{l}0,253 \\
(4,14)\end{array}$ & $\begin{array}{l}0,014 \\
(321)\end{array}$ & 0,044 & $(6.564)$ & 0.571 & 0.97 & 0.4955 & 0.46 \\
\hline $119551 \mathrm{~N} 197$ & $\begin{array}{r}0.001 \\
(1,31)\end{array}$ & $\begin{array}{l}0,253 \\
(420)\end{array}$ & $\begin{array}{l}0,013 \\
(3)\end{array}$ & $\begin{array}{l}0,045 \\
2.56)\end{array}$ & $\begin{array}{l}0.555 \\
(6.54)\end{array}$ & 0.571 & 101 & 0.4938 & 071 \\
\hline $111955-1 / 1978$ & $\begin{array}{l}0,001 \\
(136)\end{array}$ & $\begin{array}{l}0237 \\
(3.96)\end{array}$ & $(301)$ & $\begin{array}{l}0,042 \\
(2,40)\end{array}$ & $\begin{array}{l}0.562 \\
(6.63)\end{array}$ & 0.542 & 128 & 0.5048 & \\
\hline
\end{tabular}

ined empirically - its estimation will avoid the problem associated with the Cochrane-Orcutt technique. ${ }^{15}$ Thus, in this very important sense, estimation of equation 13 is preferable.

15 First-differencing has been suggested as a means of avoiding the econometric problems associated with nonstationary error structures. See C. W. J. Granger and P. Newbold, "Spurious Regressions in Econometrics," Joumal of Econometrics (June 1974) pp. 111-20; and D. Williams, "Estimating in Levels or First Differences: A Defense of the Method Used for Certain Demand-for-Money Equations," The Economic Joumal (September 1978), pp. 564-68.

As an additional important matter, Charles I. Plosser and G. William Schwert, "Money, Income, and Sunspots: Meas-
Both the real- and nominal-adjustment versions of the money demand relationship were estimated in first-difference form. The respective findings are reported in tables 5 and $6 .^{16}$

Consider first the results for the real-adjustment

turing Economic Relationships and the Effects of Differencing, Journal of Monetary Economics (4: 1978), pp. 637-60, show that the econometric problems of "overdifferencing" an equation are not as severe as those of "underdifferencing."

16 A constant term was included in the specification to ascerm tain whether a time trend is evident in money denand. If there is a trend in money demand, the trend rate of change 


\section{Table 6}

\section{Nominal-Adjustment Version: Log Differences (ordinary least squares)}

\begin{tabular}{|c|c|c|c|c|c|c|c|c|c|}
\hline Pellod & $\begin{array}{l}\text { Coofficte } \\
\text { Constant }\end{array}$ & $\begin{array}{l}\text { labsols } \\
\text { n }_{\text {nyt }}\end{array}$ & 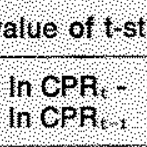 & $\begin{array}{l}\text { istics n pr } \\
\text { nमTD, } \\
\text { In RTD }\end{array}$ & 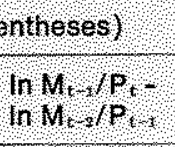 & $\mathrm{P}^{\prime}$ & OW. & $\begin{array}{l}5 E \\
\times 10\end{array}$ & $\begin{array}{l}\text { static } \\
4 \mathrm{MSE}^{\circ} \\
\end{array}$ \\
\hline $11 / 1955 \mathrm{~N} / 1962$ & $(0.51)$ & $\begin{array}{l}0.170 \\
(2.26)\end{array}$ & $(0.018)$ & $\begin{array}{l}0.027 \\
(1.61)\end{array}$ & $\begin{array}{l}0.702 \\
(4.96)\end{array}$ & 0.613 & 2,16 & 0.3896 & 021 \\
\hline $11 / 1955 \mathrm{~N} / 1968$ & $\frac{0.0002}{(0.27)}$ & $\begin{array}{l}0.175 \\
(2.47)\end{array}$ & $\begin{array}{l}0.018 \\
(3.78)\end{array}$ & $\begin{array}{l}(0,029 \\
(1.89)\end{array}$ & $(0,736)$ & 0.669 & 215 & 03688 & 0,4 \\
\hline W/1955-W/1964 & $(00009)$ & $\begin{array}{l}0,171 \\
2,46)\end{array}$ & $\begin{array}{r}0.018 \\
(3,79)\end{array}$ & $\begin{array}{l}0.031) \\
(1.99)\end{array}$ & $\begin{array}{l}0.730 \\
(6.49)\end{array}$ & 0.683 & 213 & 03736 & 0,41 \\
\hline $11 / 1955-11 / 1065$ & $(-0.0001)$ & $(0.169)$ & $\begin{array}{c}0.019 \\
(3.90)\end{array}$ & $(0,031$ & $\begin{array}{l}0.742 \\
(6.60)\end{array}$ & 0.675 & 2.03 & 0.3772 & 0.61 \\
\hline $11 / 95514 / 966$ & $(0,6000 \%$ & $(0,684$ & $\left(\frac{0.019}{(3.80)}\right.$ & $(1,65)$ & $(0.701$ & 0.627 & 1.95 & 0.4020 & 0,61 \\
\hline $11 / 195511 / 1967$ & $\begin{array}{l}0.0003 \\
(0.28)\end{array}$ & $\begin{array}{l}0.193 \\
(2.64)\end{array}$ & $\begin{array}{r}0.020 \\
(3.90)\end{array}$ & $\begin{array}{r}-0.032 \\
(1.87)\end{array}$ & $\begin{array}{l}0.683 \\
(6.15)\end{array}$ & 0.606 & 196 & 0,4230 & 0.30 \\
\hline $1 / 1955 / V / 1968$ & $(0.0001$ & $(2.808)$ & $\begin{array}{l}0.020 \\
(4.06)\end{array}$ & $\begin{array}{l}0.033 \\
(1,99)\end{array}$ & $\begin{array}{l}0.697 \\
(6.62)\end{array}$ & 0.620 & 195 & 0,4141 & 0.32 \\
\hline $11 / 1955-11 / 1960$ & $(0.46)$ & $\begin{array}{l}0.209 \\
(3.10)\end{array}$ & $\frac{0.022}{(4.55)}$ & $\begin{array}{l}0,031) \\
(1.94)\end{array}$ & $\begin{array}{l}0,699 \\
(7,11)\end{array}$ & 0,638 & 1,95 & 0.4072 & 0,17 \\
\hline $11 / 1955 \% / 1970$ & $(0.0003)$ & $(0.205)$ & $\begin{array}{l}-0.021 \\
(4.71)\end{array}$ & $\begin{array}{r}0,029 \\
(1,88)\end{array}$ & $\begin{array}{l}0.692 \\
(731)\end{array}$ & 0.642 & 1,92 & 0,3953 & 073 \\
\hline 111955411971 & 0,0002 & $\begin{array}{l}0,66 \\
(2.65)\end{array}$ & $\begin{array}{l}0.016 \\
(3.70)\end{array}$ & $(20063)$ & $\begin{array}{l}0.658 \\
(694)\end{array}$ & 0.591 & 178 & 0.4185 & 0,38 \\
\hline $1 / 1955-1 / 1972$ & $(0,000)$ & $\begin{array}{l}0,84 \\
(3,10)\end{array}$ & $(4,03)$ & $\begin{array}{l}0,035 \\
224)\end{array}$ & $(7,38)$ & 0,617 & 1.94 & 0.4151 & 0.38 \\
\hline $1 / 7955-v / 1973$ & $\begin{array}{l}0.0002 \\
(0.29)\end{array}$ & $\begin{array}{l}0,183 \\
(3,6)\end{array}$ & $\begin{array}{l}0,016 \\
(4,05)\end{array}$ & $\begin{array}{l}-0032 \\
(2.11)\end{array}$ & $\begin{array}{l}0.669 \\
(7.71)\end{array}$ & 0,628 & 1,99 & 04127 & 048 \\
\hline $1 / 1955$ V//1074 & $\begin{array}{l}0,001 \\
(0.78)\end{array}$ & $\begin{array}{l}0.194 \\
(3.45)\end{array}$ & $\begin{array}{l}0,017 \\
(4,69)\end{array}$ & $\frac{0.027}{(1.81)}$ & $\begin{array}{l}0.728 \\
(9.21)\end{array}$ & 0.702 & 212 & 04142 & 0,81 \\
\hline $1 / 19551 \mathrm{~V} / 1075$ & $\begin{array}{l}-0,001 \\
(1.67)\end{array}$ & $\begin{array}{l}0.232 \\
(4.20)\end{array}$ & $\begin{array}{l}0.015 \\
(3.88)\end{array}$ & $\begin{array}{l}0.025 \\
(1.59)\end{array}$ & $\begin{array}{l}0.709 \\
(8.87)\end{array}$ & 0.683 & 202 & 0,4394 & 0.43 \\
\hline $11 / 1955-1 / 1976$ & $(1.60)$ & $\begin{array}{l}0,230 \\
(4,28)\end{array}$ & $(3.08)$ & $\begin{array}{l}0,026 \\
(167)\end{array}$ & $\begin{array}{l}0,700 \\
(8.85)\end{array}$ & 0.672 & 210 & 0.4387 & 025 \\
\hline $111955-1 / 1977$ & $\begin{array}{r}0.001 \\
(1.62)\end{array}$ & $\begin{array}{l}0.226 \\
(4.33)\end{array}$ & $\begin{array}{l}0.014 \\
(3.90)\end{array}$ & $\begin{array}{l}-0,026 \\
(1,68)\end{array}$ & $\begin{array}{l}0.706 \\
(9.10)\end{array}$ & 0.672 & 2,12 & 0.4317 & 0,45 \\
\hline $1195514 / 1978$ & $(1,71)$ & $\begin{array}{l}0,221 \\
(4,36)\end{array}$ & $\begin{array}{r}0.016 \\
(424)\end{array}$ & $\begin{array}{l}0,024 \\
(155)\end{array}$ & $\begin{array}{l}0.717 \\
(9.61)\end{array}$ & 0.665 & 210 & 0.4319 & 4 \\
\hline
\end{tabular}

specification in table 5 . The Durbin-h statistics indicate that, for sample periods ending beyond IV/1964, there is no evidence to reject the hypothesis of serially independent error terms: It is only in the earlier sam. ple periods that evidence of first-order autocorrelation exists.

The regression coefficients found in table 5, like

should be equal to the constant term (see equation 13) Lieberman suggests that such a variable is relevant for money demand. See Charles Lieberman, "Structural and Technological Change in Money Demand," American Economic Review, Papers and Proceedings (May 1979), pp. 324-29. those reported in table 1 , indicate a remarkable degree of consistency as the sample period is extended. ${ }^{17}$

17In comparing the results in table 5 with those in table 1 , one should be cautioned against using the reported $\mathrm{R}^{2}$ as a basis to judge the respective equations. Granger and Newbold "Spurious Regressions," show that when the dependent and independent variables follow a random walk, as they do in our specification, a nonzero $\mathbf{R}^{2}$ will be expected, even if no relationship between the variables actually exists. When the equation is estimated in first-difference form, the variables no longer follow a random walk and thes $\mathrm{R}^{2}$ is expected to be zero.

Furthermore, the reader is cautioned against solely using the $S E E$ as a basis of comparison. Recall the aforementioned econometric problems associated with the Cochrane-Orcutt estimation results. 


\section{Table 7}

\section{Mean Static Prediction Error* (billions of nominal money balances)}

\begin{tabular}{|c|c|c|}
\hline $\begin{array}{l}\text { Prediction } \\
\text { interval }\end{array}$ & $\begin{array}{l}\text { Real-adjustment } \\
\text { (First-difference } \\
\text { estimation) }\end{array}$ & $\begin{array}{l}\text { Nominaladiustment } \\
\text { (First-diference } \\
\text { estimation) }\end{array}$ \\
\hline $1 / 1974-\mathrm{IV} / 1974$ & $\$ 1,65$ & $\$ 0,82$ \\
\hline $1 / 1975 / \mathrm{V} / 1975$ & $\checkmark 0.91$ & 1,40 \\
\hline $1 / 1976 / V / 1976$ & +0.10 & 10.14 \\
\hline $1 / 1977 \mathrm{~N} / 1977$ & 10.17 & $? 0.10$ \\
\hline //1978-IV/1978 & -1.24 & -0.74 \\
\hline
\end{tabular}

Biror is calculated as actual nominal mones stoek less pre dicted nominal money stock $A$ negative errot thus ndicates overprediction.

With the single exception of the coefficient on the passbook rate for the sample period ending in IV/ 1971, the estimated coefficients all change by less than one standard error.

The regression coefficients in table 5 are also similar to those found in table 1 in other respects. ${ }^{18}$ The coefficient on the lagged dependent variable indicates a significant partial adjustment to the desired level of real money balances. The relatively smaller coefficient in table 5 indicates, however, a larger coefficient of adjustment - ranging from 0.39 to 0.47 . The findings in table 5 again support the notion of economies to scale in money holdings, with the long-run income elasticity estimated between 0.33 and 0.53 . In addition, the coefficients on the interest rate variables continue to indicate a greater sensitivity to a propor tional change in the passbook rate than the commercial paper rate.

An important improvement obtained from the firstdifference estimation procedure over the levels results is the post-sample performance. Table 5 indicates a deterioration in post-sample performance over the 1974-75 period, but the deterioration is slight relative to that found in table 1. Not only are the RMSEs consistently lower for the first-difference results, but this specification does not consistently overpredict money demand over the post-1974 period. In fact,

\footnotetext{
${ }^{18}$ As stated previously, the estimated constant term has no counterpart in the levels fom of the real-adjustment specifcation. This coefficient, while never significantly different from zero in table 5, does change as the sample period is extended to include the 1974 observation. When post-1974 observations are included in the sample, both the sign and magnitude of this coefficient are in accord with Lieberman's findings. This suggests a slight, but statistically insignificant negative drift in the relationship, which is unexplained by other variables.
}

table 7 indicates that this specification slightly under predicts money demand on average for 1976 and $1977 . .^{19}$

In contrast to the first-difference estimation of the real-adjustment mechanism, table 6 shows that there is no evidence in the nominal-adjustment specification of any first-order serial correlation in the disturbances. The Durbin-Watson statistics reveal no problems associated with serial dependence in the errors.

Many of the previous comparisons between the real- and nominal-adjustment levels estimations (tables 1 and 2) continue to hold for the first-difference estimations. The coefficient of adjustment remains smaller for the nominal-adjustment specification than for the real-adjustment specification in table 5. The other regression coefficients continue to be fairly similar to those found for the real-adjustment equation. The coefficient on the passbook rate for the nominaladjustment specification is not, however, significantly different from zero over many of the sample periods. Again the SEEs and the RMSEs are consistently smaller for the nominal-adjustment specification, indicating a better in- and out-of-sample fit. Table 7 also shows that using the first-difference of the nominaladjustment specification not only leads to a smaller forecasting error on average, but more importantly, alleviates the persistent problem of overprediction which plagued the levels estimation. ${ }^{20}$

Unlike those observed in table 2 , the regression coefficients in table 6 do not change dramatically as the sample period is extended beyond IV/1973.21 The

19It should also be noted that the mean overprediction that takes place in 1978 is in large part due to overpredicting money demand in the fourth quanter of that year, when ATS accounts were legalized nationwide and NOW accounts were legalized in New York.

$20 T_{0}$ determine if the inclusion of the constant term seriously biases the post-sample performances of the equations, forecasts based on equations that exclude the constant term were made. For the real-adjustment equation, the most signiffeant effect is to change the sign on the mean static prediction for the interval I/1976-IV/1976 from plis to minus. The mean error, however, for the period is $\$ \$ 0.02$ billion, quite small relative to that reported in table 7 . For the nominal-adjustment specification, the positive signs for $1 / 1976-\mathrm{IV} / 1976$ and I/1977-IV/1977 are changed to negative when the constant term is omitted from the forecasting equation. As with the real-adjustment equation, however, the mean errors are very small relative to those reported in table $7:-\$ 0.002$ billion for I/1976-IV/1976 and $-\$ 0.07$ billion for I/1977-IV/1977. These results suggest that it is first-dirferencing, rather than the indusion of the trend variable in the specification, that is most responsible for the improved forecasting accuracy of these specifications.

21'The possible exception to this is the behavior of the estirikated constant term. This coefficient estimate increases (in absolute value terms) five-fold as the 1974 observations are added to the sample period. While the change in this coefficient is noticeable, it is important to bear in mind that this coefficient estimate is never significantly different from zero. 
changes that occur, instead, are relatively minor. This is especially true of the coefficients on the real income and lagged dependent variables. Thus, the use of firstdifferences apparently has resulted in a more stable relationship.

Chow tests again were used to determine whether either of these first-difference relationships is statistically stable over the full-sample period. The F-statistics for the same hypothesized break points considered previously ( see table 4) are provided in table 8. ${ }^{22}$ These statistics indicate that neither of the specifications is statistically different over any of the alternative subperiods considered. This suggests that the previous evidence of breakdowns in these relationships is the result of the estimation technique employed. The first-difference estimation results, which are econometrically preferable, show no evidence of structural breakdown in either of the money-demand specifications considered.

\section{SUMNARY AND CONCLUSION}

This paper has investigated two alternative stockadjustment mechanisms employed to empirically explain money demand. In addition, two alternative procedures have been used to estimate these relationships. The results indicate that both stock adjustment relationships are statistically stable when esti-

2 Since the disturbances for the first-difference equation are serially independent, the Chow test results reported in table 8 avoid the problen of serial dependence in the error terms that plagued the previous tests.

In an alternative test, the first-difference equations were estimated without a constant term and the Chow test was used to test the stability of these equations. Using the same hypothesized break-points as in table 8 , the test results indicate that stability cannot be rejected at the 5 percent level of significance (e.g., the largest calculated $F$-value is 0.69 ). Thus, exclusion of the constant tern does not adversely af fect the stability finding.

In addition, the type of Chow test described in footnote 13 was specifically used to test if the constant term should be allowed to vary across the various subperiods. For each equation and the different subperiods, the calculated F-statistics were well below standard critical valnes. Thus, no statistical advantage is ganed by allowing the constant term to take on different values in altemative subperiods.
Table 8

F-statistics for Null Hypothesis that Regressions Are Equal in Two Alternative Sample Periods (first-difference)

\begin{tabular}{|c|c|c|}
\hline sample perods & $\begin{array}{l}\text { Red } \\
\text { astment }\end{array}$ & $\begin{array}{l}\text { Nommal } \\
\text { adjustment }\end{array}$ \\
\hline $1 / 1955 \mathrm{~N} / 1962$ vs $1 / 1965 / 4 / 1970$ & 0,47 & 0.44 \\
\hline $1 / 1955 / 1967$ vs $/ 1966-1 / 978$ & +1 & 102 \\
\hline $11955 \mathrm{~N} / 973 \mathrm{vs} / 1974 \mathrm{~N} / 978$ & 12 & 1,05 \\
\hline $1 \%$ ortical value, 3.21 & & \\
\hline $5 \%$ crifoalvalle, 233 & & \\
\hline
\end{tabular}

mated in first-difference form. This suggests that much of the recent evidence of a breakdown in the money-demand relationship is the result of the estimation technique employed. To the extent that the nominal-adjustment specification consistently provided a better fit (both in-and out-of-sample), the evidence presented here further suggests that a relaxation of the assumption that the money stock adjusts to a price level shock within the quarter is worthwhile.

Furthermore, the results presented in this paper deny the claim that monetary policy is impotent as a result of a shifting money-demand relationship. Those who argue this point recently have suggested that attempts to control inflation through restrictive monetary policy will be unsuccessful since the money demand relationship is unstable. The findings of stability presented here seriously question this assertion. It does not appear that the relationship between money demand, real-income, and interest rates has changed significantly over recent periods. The surprisingly accirate predictions of money demand over the post-1973 period using the first-difference approach buttress the conclusion that the money-demand relationship has not suffered from any drastic shifts that would invalidate monetary policy.

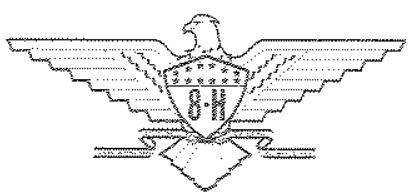

